\section{THE ROYAL COLLEGE OF CHEMISTRY}

\author{
By DR. E. FRANKLAND ARMSTRONG, F.R.S.
}

$\mathrm{T}$ HE centenary of the founding of the Royal College of Chemistry in October 1845 is an occasion on which we may well take stock of its influence on the progress of pure and applied chemistry in Britain.

The stiory of the hundred years is a story of men and not of laboratories - of professors and disciples, of enthusiasm and of hard work for its own sake. Laboratories are never large enough or sufficiently equipped-perhaps in Britain they never will be-but the great man rises superior to his physical surroundings or handicaps and the student is surely all the better fitted to face the future when not pampered. Latent powers are best evoked by sufficient severity of circumstances, as the long history of our race bears abundant testimony.

In the 1840's things were changing; a nation of countrymen was slowly turning into a nation of townsmen. It was an age of movement, of traffic on canals faster than the coaches on the roads, and on steam railways faster still. It was an age of wheels, wheels at the pit head, spindles in the cotton and woollen mills. The pace of life was quickening on every side.

In 1842 all England was agog: that great man Baron von Liebig was on tour in the industrial Midlands and North. The tour was personally conducted by none other than Lyon Playfair, who took care that Liebig should meet the most influential people and impress on them the national importance of the new science of experimental chemistry. Such a triumphal tour made its influence felt in all the chief centres of Great Britain. At the end of his visit, Liebig is reported to have said "England is not the land of Science"; a hundred years later there is still very much to be done before we can claim to be entirely free from this reproach.

Liebig's tour helped to direct attention to chemistry and make it a popular science, for it must be remembered that at this time it was very seldom that any students desired to become chemists. The Pharmaceutical Society claims that the first laboratory open to students was one under its auspices with Fownes as teacher. This would be in the early ' 40 's, and he was the author of a text-book "Fownes' Chemistry". Jacob Bell, the then president, would have made the pharmacy into an Apotheke-not a druggist or a fancy goods store-had he been listened to. There were already courses at University College and King's College, London, in which chemistry was taught as part of the training for other professions. The promoters of the Royal College of Chemistry sought, however, to do something new by founding an institute in which chemistry would be studied for its own sake apart from professional requirements. It was anticipated that the students who came there would make chemistry the occupation of their lives and enlarge its boundaries by research in the laboratory.

The first effort of the enthusiasts, inspired by Liebig's visit, was to attempt to found a Davy College of Practical Chemistry within the Royal Institution. This effort did not succeed, but it led to further meetings and so the Royal College came into being. Two men share the credit for its foundation, Sir
James Clark, the Queen's physician, and the Prince Consort. The Prince Consort was at that time president of the Society of Arts, in the affairs of which he took an active part, often presiding at council meetings. His contact there with men of science must have supplemented his personal interest in these matters and he was eager to lead the nation to take science seriously. But a new college of this kind could not have been created unless there had been a strong popular feeling in its favour. All depended now on securing the right leader. The advice of Liebig was sought; Fresenius and Will both refused, Hofmann was dubious about accepting, as failure of the new college would retard his career in Germany. Once again the Prince Consort intervened, and it was thanks to his efforts that Hofmann was given two years leave of absence from Bonn so that he might, if necessary, at once re-enter on his career in Germany. The choice was a happier one than anyone knew. Hofmann became not only the greatest research leader of his day; he evinced many other attributes which contributed to the success of the new enterprise.

Hofmann made a start in the temporary laboratories at George Street, Hanover Square, in October 1845. A year later it was possible to commence work in the new building in Oxford Street backing on Hanover Square. There were twenty-six students in the first course, among them E. C. Nicholson, F. A. Abel and, above all, Warren de la Rue, who more than anyone else helped Hofmann. Others were Henry How, Thomas Rowney, C. L. Bloxam, Robert Galloway.

The second batch of students brought thirty-seven more, including C. B. Mansfield and George Merck, F. Field, H. M. Noad, Bransby Cooper and John Blythe. It is to be noted that Hofmann's rising fame soon attracted his own countrymen to his laboratory, particularly as his private assistants, who included Peter Griess, the discoverer of the diazo reaction, and Martius. Other distinguished names of this early period were Crookes, Spiller, Tookey, Reginald Morley, Groves, Ansell, Church, Matthew Johnson, H. M. Witt, H. McLeod, Valentin, Barrett, Bassett, Vacher, O'Sullivan and Reynolds.

From its earliest beginning the duty of the College has been to produce men, leaders in their chosen walk in life. The professors, by their example, precept and teaching, encouraged a progeny keen on enlarging the boundaries of knowledge, able in their turn to teach and inspire a later generation. Science for its own sake, unfettered and unrestricted, must still be the keynote of its activities, even though to-day science has its practical applications to the daily avocations and health of the people and in the development and progress of industry. Unfortunately, the nation at large is barely science conscious, and it will remain indifferent until science, particularly scientific method, is more widely taught in the schools.

In 1851 the Government School of Mines and of Science Applied to the Arts was founded in Jermyn Street, with Playfair as its professor of chemistry. Some confusion exists about Playfair's post, which need not be discussed here. He retired in favour of Hofmann when the two colleges were incorporated in 1853 as the Metropolitan School of Science Applied to Mining and the Arts, which in 1863 had its name changed to the Royal School of Mines. In spite of the official incorporation, the Royal College maintained some measure of independent existence and 
continued to confer its own diploma until it moved to South Kensington in 1872, where it became part of the Normal School of Science in 1881. At the same time the departments of biology, physics and applied mechanics went there from Jermyn Street. The building in which they were all housed became known later as the Huxley Building.

In the wake of the 1851 Exhibition, and fostered by the newly created Department of Science and Art, a demand spread throughout Britain for instruction in science subjects-given mainly if not almost entirely in evening classes-among which chemistry was predominant, physics, botany and geology also attracting many students. These classes, promoted or recognized by the Department of Science and Art, were financed largely during many years by payments based on the success of the students in its examinations. To meet this demand for more advanced instruction, yearly a number of selected junior teachers of, and promising students from, recognized classes received free education and maintenance in the College after its removal to South Kensington in 1872 .

In 1881 the name of the college was changed to the Normal School of Science, and in 1890 to the Royal College of Science, to mark enlargement and consolidation of its scope and functions-among which from its earliest days was a special reference to the applications of chemistry to "the Arts and Manufactures". Its students could be classified under the headings : fee-paying, exhibitioners; teachers in training (Science and Art Department) ; and, between c. 1886 and 1902, Inland Revenue and Excise (customs) officers taking either the one- or the two-year course in chemistry. The academic year was divided into two and not three terms and in each term only one subject was studied ; chemistry, with some mathematics, being taken by all associateship students in their first term as the initial subject of their course.

Hofmann resigned and went to Berlin in 1865; he was succeeded by Edward Frankland. Edward Thorpe succeeded Frankland in 1885 and five years later the title Royal College of Science was born. William Tilden followed Thorpe in 1894. Frankland received the K.C.B. ; Thorpe and Tilden were knighted in recognition of their services to chemistry.

The changes of name of the College are somewhat bewildering. In fact, for some thirty years, during 1851-81, there was a conflict of divergent aims and interests between the party led by Huxley and the Science and Art Department, which wanted a great metropolitan school embracing all branches of applied science, and the mining school opposition which did not want to see the development of the Jermyn Street school hampered. It was in reality a conflict over lack of space, a basic trouble which will always be true of a growing college.

On the foundation so truly laid by the Prince Consort, the edifice built by Hofmann has endured a hundred years. Founded in days when chemistry could scarcely be called a science, no fairy tale can match the wonders of the progress of chemistry and of the dye industry which it is the proud boast of the College to have originated. The torch borne in turn by Hofmann, Frankland, Armstrong, Thorpe, Tilden, Japp, Wynne, Morgan and so many more still burns as brightly. The laboratories of the Royal College have sent out into the world men who have given us clean water, dyestuffs, and brought progress to every branch of pure and applied chemistry. Those who have taught have handed the ideals on to their students, who have in time permeated to every univer. sity in the land. A genealogical tree to-day would show few chemists who do not claim descent in some way from Hofmann or one of his three successors.

Although the first discovery of benzene is properly attributed to Faraday, it was Hofmann who, needing aniline, the key substance of the dyestuff industry, for his researches and hampered by the very small yield obtainable from indigo by distillation with alkali, discovered in 1845 how to convert benzene into nitrobenzene and reduce this readily to aniline. To-day we should still regard this as the most important reaction in organic chemistry. Thereupon Mansfield was set to work on benzene in the Oxford Street laboratory, and not only separated it from coal tar and showed how it could be prepared on the large scale, but also emphasized that it could be procured to any extent from this hitherto waste product.

Very soon afterwards, the aniline colour industry came into existence with Perkin's discovery of mauve in 1856, followed soon by an anthracene industry and an azo colour industry. Synthetic dyestuffs had arrived. All these centred around the College of Chemistry the men who made them possible were Hofmann, Perkin, Griess, Nicholson, Simpson, Maule. Hofmann did his best to raise up an English tree of organic chemical industry, and for a while it grew apace. He was perhaps the first to urge that while capital can do much, capital directed by the lights of science may accomplish much more.

One of Hofmann's talents was his faculty of gauging the powers and special qualifications of those who studied under him. All who worked with him were stirred to enthusiasm, and failure to produce results was a real personal grievance. My father has written that "he made the student his personal instrument -no one has ever been more avaricious of results and he was always carried forward by this desire". Frankland, who succe日ded him, had no such tendency; he had peculiar difficulty in getting behind the students' work and finding out what had been done. Only those could work effectively with Frankland who needed little, if any, guidance. $\mathrm{He}$ let his students handle things for themselves and so gain an intuitive understanding of the method of discovery. His manner of lecturing was the very antithesis of Hofmann's, but his lectures were more impressive on account of the wealth of fact and the attention he gave to the experimental side. He was both a pioneer of research and of structural formulæ, and undoubtedly England's greatest chemist of his time.

In 1868 Frankland became a member of the Royal Commission appointed to inquire into the pollution of rivers and the domestic water supply of Great Britain. More than anyone else, he is responsible for giving us pure drinkable water, since he discovered that slow percolation through porous soil effected the oxidation and destruction of organic matter with great rapidity. His most famous pupil was $H$. E. Armstrong, who went to the College in Oxford Street just as Hofmann was leaving. Armstrong had two years and a term there, the last year or more being spent in the privatelaboratory working on the revision of the methods of water analysis.

Armstrong left Frankland late in 1867 to work for two and a half years with Kolbe in Leipzig. $H_{\Theta}$ has written that the return of a prodigal son from Ger- 
many was then a novelty; owing to Hofmann being in London and Liebig no longer an attraction, the habit of studying chemistry in Germany had ceased among English students : it set in again, but only gradually, owing to the enforced emigration of holders of research scholarships awarded by the Royal Commission of the 1851 Exhibition.

Armstrong worked first at the London Institution and then took the leading part in the establishment and development of the Finsbury and Central Colleges. His research school at South Kensington was worthy of the traditions of Hofmann and Frankland, and such men as Wynne, Kipping, Pope, Forster, Lowry, Heller, Rich, Renwick, Rodd and many others developed there. In the main, its students went into the chemical industry, and almost without exception they have distinguished themselves by playing a leading part in their chosen industry and its development.

T. E. Thorpe came to the College as its third professor of general chemistry and technology in 1885 from Leeds. Whereas his predecessors had been essentially organic chemists, Thorpe's interests lay in the inorganic and physical sections of the subject. He was a polished writer and also administrator and publicist. Thorpe had other wide scientific interests, taking part in eclipse expeditions and the magnetic survey of Britain. Some of his scientific work at the College concerned the determination of atomic weights of silicon with J. W. Young, of gold with A. P. Laurio-while phosphorus compounds were studied with J. W. Rodger, Hambly and Tutton. $\mathrm{He}_{\boldsymbol{\theta}}$ left to become the director of the Government Laboratories. Small in stature, he was a man of outstanding virility, and his example quickened the spirit of a band of devoted students and staff. Thorpe came back to the College on Tilden's retirement for three years to tide over the period until the Imperial College had come fully into being.

The Chemistry Department in Thorpe's days was housed in the Huxley Building in one large lecture theatre, two analytical laboratories designated North and South on the third floor, a long corridor-like room on the second floor facing west used for research, and several private rooms. The fittings and equipment, doubtless installed in 1872, were already oldfashioned. It is worth while pointing out how quickly a chemical laboratory grows out of date-a new one is required at least every thirty years. It is perhaps desirable to consider whether palatial and costly solid buildings should be erected for such purposes, or whether more simple structures would not be more practical and economical. They could be rebuilt every ten or fifteen years and kept continually up to date.

In 1894, W. A. Tilden from the Mason College, Birmingham, followed Thorpe. Much of his time was devoted to teaching and administrative duties, including that of dean (1905-8), and his own experimental work, largely concerned at that time with a systematic study of specific heat, was interrupted. His earlier researches had been in organic chemistry, notably the first discovery of the polymerization of isoprene to rubber, work in which M. O. Forster, then his private assistant, had a hand. Tilden's period covered a transference of the Chemistry Department from the Huxley Building to its present domicile in Imperial Institute Road: the design, construction and fitting of the new laboratories involved much of his time.

H. B. Baker succeeded Sir Edward Thorpe as professor of chemistry on the latter's retirement in 1912 and the opportunity was taken to found separate chairs of physical and organic chemistry to which J. C. Philip and J. F. Thorpe respectively were appointed in 1913. The Department was thus well equipped to deal with chomical problems arising out of the First World War, in the investigation of which it took no small share. With the return of peace, Baker resumed his study of the influence of complete dryness on the physical and chemical properties of solids, liquids and gases. On his retirement in 1932, he was succeeded by H.V.A. Briscoe, a former student (1906-9) and member of the staff, who came from King's College, Newcastle-upon-Tyne, and on the retirement of J. F. Thorpe in 1940, I. M. Heilbron of the University of Manchester succeeded to the chair of organic chemistry, the chairs of chemistry reverting to two in number after the death of $J$. C. Philip in 1941.

In the building up of the great school of chemistry at South Kensington, the non-professorial members of the staff had a large share: some gave long and devoted service, while others in due course accepted. professorships elsewhere. Only a few names can be mentioned in the space available; those omitted are in no sense forgotten by their students.

F. R. Japp was chosen by Frankland in 1878 to take charge of the Research Laboratory which was then being established, and to devote his whole time to the supervision of the research students. In 1881 he was promoted assistant professor. Japp had worked abroad with Kekulé and Anschütz; he spent twelve years in London, where he gathered around him a large number of able and enthusiastic students, and research was prosecuted with great activity. Finally he went to Aberdeen and founded there a school of advanced chemical study.

W. P. Wynne succeeded Japp; he had been a student at the College during 1881-85, and then joined H. E. Armstrong at the Central, where for many years they were jointly engaged on studies of the constitution of naphthalene derivatives and of the many isomeric naphthalene intermediates for dyes ; the manufacture of these and of the derived dyestuffs, alas, was by then largely in German hands. He returned to the College as assistant professor in 1891, but left in 1902 to go to the Pharmaceutical Society and in 1904 became professor at Sheffield.

A. E. H. Tutton came to the Normal School as a student in 1883 and, after work on the oxides of phosphorus in collaboration with Thorpe, began about 1892 the measurement and description of the crystals of organic substances prepared in the Chemical Laboratory. Self-taught in the subject, crystallography became the dominant passion of his life, and for forty years he investigated the effect produced on crystal form and physical properties by the replacement of one element by another in a series of allied compounds. In 1895 he became H.M. Inspector of Schools (Technical), Board of Education.

G. T. Morgan was a student at Finsbury under Meldola. $\mathrm{He}$ first went into the dye industry at Huddersfield for five years, and entered as a student at the Royal College under Tilden in 1894. There he quickly passed to the staff and began a varied research programme indicative of the width of his future interests. He stayed there until his appointment to Dublin in 1912. Four years later he went to Finsbury and in 1919 to Birmingham, becoming in 1925 the director of the Chemical Research Laboratory instituted after the War of 1914-18 as part of the 
Government scheme for promoting industry on scientifie lines. Morgan inspired a large number of students, a high proportion of whom went into industry; and he turned his attention continually to now fields of investigation, showing remarkable versatility. Diazo reactions of aromatic diamines; organic compounds of phosphorus, arsenic and antimony; high-pressiure reactions; base exchange materials; synthetic resins; low-temperature tars, were only a few phases of his activities. Few men have done more than Morgan to carry the torch kindled by Hofmann along the highways of England, and to take chemical knowledge and scientific method into the lives of many as teacher, colleague and friend.

M. O. Forster likewise started at Finsbury, then went to Würzburg, where he took his degree and came back to the Central as Salters' Company Research Fellow. He came to the Royal College as demonstrator in 1895, being promoted assistant professor in 1902, a post he held until 1913. Forster carried out a brilliant series of organic researches from the College and was an inspiring influence there. He went to British Dyes during a troubled period, was later first director of the Salters' Company's Institute of Industrial Chemistry and four years later went to Bangalore as director of the Indian Institute of Science, where he did outstanding work for Indian science.

J. C. Philip, an Aberdonian and a pupil of Japp, studied under Nernst in Göttingen, and after a year with H. E. Armstrong at the Central gave a course of lectures in physical chemistry at the Royal College at the invitation of Tilden; he became lecturer there in 1900, assistant professor when Thorpe returned to the chair in 1909, and professor of physical chemistry, a new appointment, in 1913. From then until his death in 1941, Philip was responsible for this allimportant subject. He was a teacher of great ability, and did much to establish a school of research in physical chemistry in the College during a period of very rapid growth of this branch of science.

J. F. Thorpe was a student of the Royal College in 1892-93, but developed largely under the influence of Auwers in Heidelberg and of W. H. Perkin, jun., at Manchester. He came back to the College when the chair of organic chemistry was created there in 1913, and there attracted and inspired a following of staff and research students in part because of his remarkably neat and effective technique. Under his leadership, research in organic chemistry flourished in spite of the interruption caused by the First World War. J. F. Thorpe later devoted the greater part of his time to administrative work and to Government committees, but the school continued to flourish under his assistants, among whom were included Ingold, Linstead, Farmer and Kon.

The College has played its part also in the provision of standard chemical literature without which the progress of research would be greatly hampered. The famous "Thorpe's Dictionary of Applied Chemistry" was first published in 1890 in three volumes : in its compilation, Sir Edward Thorpe had the assistance of many of the College staff besides outside collaborators. A second edition in five volumes began to appear in 1912, and a third in 1921. The First World War emphasized the value of the work and the need for a further revision. This was undertaken by J. F. Thorpe and M. A. Whiteley, thus maintaining the association of the "Dictionary" with the chemistry staff at South Kensington. It has become clear that pure science and technology cannot be divorced in a dictionary, so that the fourth edition of "Thorpe" now in progress is much wider in scope. Begun by Sir Jocelyn Thorpe and Dr. Martha A. Whiteley, it is being continued by a board of editors of which Prof. I. M. Heilbron is chairman, Dr. H. J. Emeléus a member, with Dr. Whiteley as editor and Dr. A. J. E. Welch as assistant editor.

Chemists are not unmindful of the important services rendered by A. J. Greenaway (1871-8I) as sub-editor of the Journal and Abstracts of the Chemical Society over a period of forty years.

Examination of the "Register of Old Students of the Royal College of Seience" confirms the impression that, in the closing years of last century, associates in chemistry found employment more easily in teaching than in industry. 'The title 'Normal School' was, rightly or wrongly, regarded as favouring this preference, owing to connotation with the French Ecole normale, although the methodology and discipline of pedagogy never formed part of the curriculum. But this preference for teaching posts need not be ascribed to predilection, as chemical industry offered relatively few openings and these none too well remunerated, with little or no assurance of security of tenure. But with the awakening of Britain to the growing need of scientific training and aptitude in industry, an improvement in prospects set in, which quickened with the growth of the present century. With the outbreak of the First World War, widespread deficiencies were revealed, and the supreme importance of research in so fundamental a subject as applied. chemistry, woing to its manifold aspects in connexion with explosives, coal, oil, metallurgy, pharmaceuticals, plastics, fabrics, food products, etc., could no longer escape recognition. Then followed the establishment of the Department of Scientific and Industrial Research, with its research associations of manufacturers, and to-day cogent evidence of the imperative need of chemistry is witnessed by urgent advertisements in the daily and technical Press and combing of the Central Register for chemists. In its contribution to the yearly academic output of some four hundred first-class honours graduates in chemistry shortly before the outbreak of the present War, and their absorption in teaching and industry, it may be claimed without fear of contradiction that the College has faithfully fulfilled the purpose of its founders - that of promoting the application of chemistry to the "Arts and Manufactures".

\section{THE ARMY SCHOOL OF EDUCATION, ELTHAM PALACE}

\section{BY MAJOR T. H. HAWKINS}

$\mathrm{A}$ NOTHER chapter in the development of adult education in Great Britain has been begun with the opening of the new Army School of Education at Eltham Palace in Kent. To those who believe that the main cultural impact on adults is social rather than strictly educational, the choice of this historical setting with its rich associations will give real pleasure.

The Palace dates far back into history. In the time of Alfred there was "a goodly residence amidst these estates" and the dwelling and demesne are mentioned in the Doomsday Book. Edward the Confessor found spiritual calm at Eltham, and the 